\title{
THE STUDY OF ANTIOXIDANT ACTIVITY OF ETHANOL FRACTION FROM BLACK CUMIN (Nigella sativa, L.)
}

\author{
Dewi Yuliani, Elok Kamilah Hayati, Tri Kustono Adi \\ Chemistry Department, Science and Technology Faculty, UIN Maulana Malik Ibrahim Malang
}

\begin{abstract}
Black cumin (Nigella sativa, L.) is a plant with a lot of advantages. Many research have been conducted on this plant and most of them use nonpolar, such as petroleum ether and chloroform, as a solvent in extraction process. In this research, extraction of black cumin using ethanol was applied.Black cumin extraction started with maceration using ethanol p.a. and partition using chloroform (1:1). The antioxidant activity of ethanol fraction of black cumin was examined by DPPH method. To identify the composition, phytochemical screening, including test for terpenoid, flavonoid, saponin, tannin and alkaloid, was also conducted.The result showed that the scavenging ability on DPPH method was $22.483 \%$ with IC50 2743.59. Phytochemical screening on ethanol fraction showed the presence of flavonoid, tannin and alkaloid. The study concluded that polar fraction of black cumin has small antioxidant activity.
\end{abstract}

Key words: black cumin, ethanol, DPPH

\section{INTRODUCTION}

Researchers have been founding that free radical has been theculprit of many diseases. Free radical, a chemical species with one or more unshared electrons, has a high reactivity and able to reaction with protein, lipid, carbohydrate, or DNA to cause human diseases. However, the diseases could be recovered with antioxidant.

Synthetic antioxidant such as tertbutyl hydroxyl anisole (BHA), tert-butyl hydroxyl toluene (BHT), and terthydroquinone (TBHQ)have been widely used to retard lipid oxidation, however, such antioxidant are not preferred due to toxicological concerns. For this reason, there has been increasing interest in the exploration of natural antioxidant especially from fruits and vegetables (Rababah et.al, 2004). One of them is black cumin (Nigella sativa, L.).

Black cumin is an annual herbaceous plant belonging to the Ranuncuaceae family, native to southwest Asia and originally a seed in East Mediterranean countries (Best, 2009). Based on haditsshahih and scientific research which has been conducted by lots of medical scientist over the world, black cumin was qualified tcure all of diseases.

Major compounds of black cumin, i.ethymoquinone

(TQ), dihidrothymoquinone (DTQ), thymol (THY) and carvacrole, have non polar properties and have function as antioxidant. In the other side, the polar compound of black cumin have been reported and showed antioxidant potency too. However, still limited research has been conducted in this subject. The information of polar compounds was not completely known. This study was trying to fulfill it by measuring antioxidant activity and identifying polar compound (ethanol fraction) of black cumin.

\section{EXPERIMENTAL PROCEDURES \\ 1. Preparation}

Black cumin seed (Nigella sativa, L.) were collected from MateriaMedica Research Center, Batu,Malang. The sample was dried under the sunlight and oven at $30-37^{\circ} \mathrm{C}$ before powdering process.

\section{Extraction of Black Cumin}

Black cumin powder was extracted by maceration and partition 
extraction.Twenty five gram of powder was soak in ethanol $100 \mathrm{~mL}$ and was shake 200 rpm for 3 hours. Maceration repeated until the extract colorless. All of the extract was concentrated under vacuum on a rotary evaporator to yield crude extract. Partition on crude extract was applied using chloroform p.a. (1:1) followed by evaporating the solvent.

\section{Antioxidant Assay}

Antioxidant activity was examined by DPPH method (Hanani, 2005). The extract was dissolved in the ethanol in various kind of concentration are 5, 50, 200, 400, 800, 1000 and 1200 ppm. Two $\mathrm{mL}$ of filtrate in the tube were added 0.5 $\mathrm{mL}$ DPPH $1 \mathrm{mM}$ and $2.5 \mathrm{~mL}$ distillated water then incubated at $37^{\circ} \mathrm{C}$ for 30 minutes. The absorbance was measured at $517 \mathrm{~nm}$.

The percentage of antioxidant activity was calculated based on the following equation (Molyneux, 2003):

$\%$ Antioxidant $=\frac{(\mathrm{Ao}-\mathrm{Ac})}{\mathrm{Ao}}$

Where, $A o=$ Absorbance of control

Ac $=$ Absorbance of sample

A percent inhibition to concentration was plotted. The concentration of sample required for $50 \%$ inhibition was determined and represented as $\mathrm{IC}_{50}$ value.

\section{Phytochemical screening}

Identification of secondary metabolite in sample was conducted by phytochemical screening including test of terpenoid, flavonoid, saponin, tannin and alkaloid.

\section{Data analysis}

Analysis of data measured the percentage of inhibition (antioxidant activity) of the sample and control. Absorbance of ascorbic acid (Asc) and BHT were the control. $\mathrm{IC}_{50}$ value was got by regression equation.

\section{RESULT AND DISCUSSION}

DPPH is one of the tests to measure antioxidant activity in inhibiting free radicals. DPPH compound have unpaired electron in outsider orbital. It gives purple color and has maximum absorbance at 517 $\mathrm{nm}$. When the electron paired, the color will turn from purple to yellow. The resulting decolorization is stoichiometric with respect to number of electrons captured. It indicated that increasing capability of antioxidant to retard free radicals compound (Prakash, 2001).

Table1 Decolorization of the extract, Asc and BHT

\begin{tabular}{|c|c|c|c|}
\hline \multirow{2}{*}{ No } & \multirow{2}{*}{ Sample } & \multicolumn{2}{|c|}{ Incubation time } \\
\hline & & Before & After \\
\hline 1 & $\begin{array}{l}\text { Black cumin } \\
\text { extract (BCE) }\end{array}$ & Purple & $\begin{array}{l}\text { Purple } \\
\text { reddish }\end{array}$ \\
\hline 2 & Ascorbic acid & $\begin{array}{l}\text { Purple } \\
\text { reddish }\end{array}$ & $\begin{array}{c}\text { Yellow } \\
\text { pale }\end{array}$ \\
\hline 3 & BHT & $\begin{array}{l}\text { Yellow } \\
\text { reddish }\end{array}$ & $\begin{array}{c}\text { Yellow } \\
\text { pale }\end{array}$ \\
\hline
\end{tabular}

Parameters used to determine antioxidant potency were the percentage of antioxidant and $\mathrm{IC}_{50}$ (Inhibition concentration). Antioxidant activity value shows capability antioxidant to inhibit freeradicals, while $\mathrm{IC}_{50}$ reveals concentration of substrate that causes $50 \%$ loss free radicals. Percentage of antioxidant activity of black cumin extract, Asc and BHT displayed in Table 2 and Figure 1.

Table 2 Percentage data of antioxidant activity in various concentration

\begin{tabular}{|c|c|c|c|}
\hline \multirow{2}{*}{$\begin{array}{c}(\mathrm{x}) \\
\text { Concentration } \\
(\mathrm{ppm})\end{array}$} & \multicolumn{3}{|c|}{ (y) Antioxidant activity } \\
\cline { 2 - 4 } & BCE & Asc & BHT \\
\hline 5 & 0.967 & 12.274 & 20.755 \\
\hline 50 & 4.184 & 23.853 & 30.709 \\
\hline 200 & 8.551 & 32.481 & 58.495 \\
\hline 400 & 11.307 & 33.397 & 85.327 \\
\hline 800 & 18.514 & 34.365 & 93.935 \\
\hline 1000 & 21.608 & 33.172 & 94.920 \\
\hline 1200 & 22.483 & 31.655 & 94.387 \\
\hline
\end{tabular}




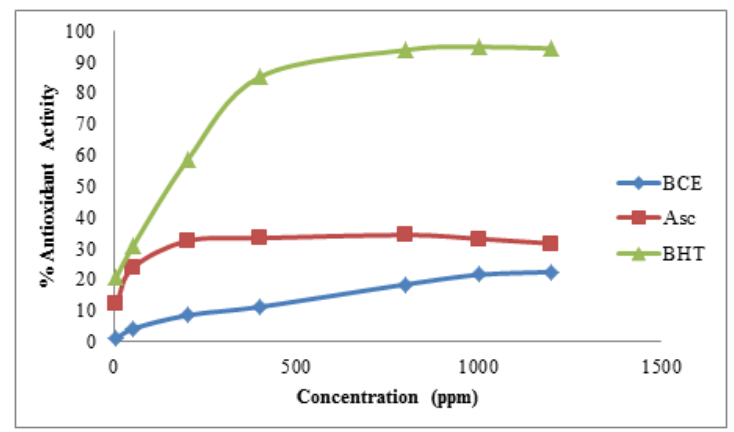

Figure 1 Graphic of antioxidant activity

Antioxidant assay using DPPH method showed $\mathrm{IC}_{50}$ value of $\mathrm{BCE}$ was 2743.59 whereas $\mathrm{IC}_{50}$ of Asc and BHT were 2685 and 213.79 , respectively.

Table $3 \mathrm{IC}_{50}$ value each samples

\begin{tabular}{|c|c|c|}
\hline No & Sample & IC $_{50}$ \\
\hline 1 & BCE & 2743.59 \\
\hline 2 & Asc & 2685.00 \\
\hline 3 & BHT & 213.79 \\
\hline
\end{tabular}

Reaction antioxidant compound and DPPH was displayed in following figure 2 .

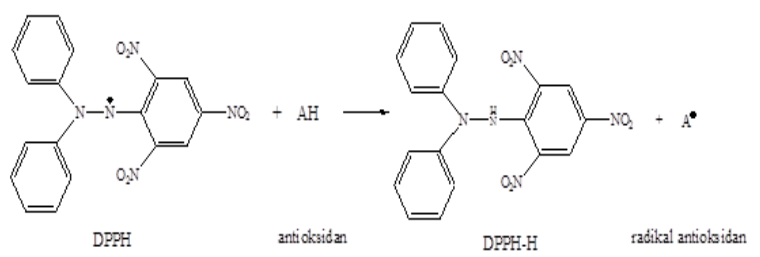

Figure 2. Reaction antioxidant compound and DPPH

Asc and BHT have inhibition mechanism different each other. Reaction BHT and DPPH was displayed in figure 3. And reaction Asc and DPPH was showed int Figure 4.

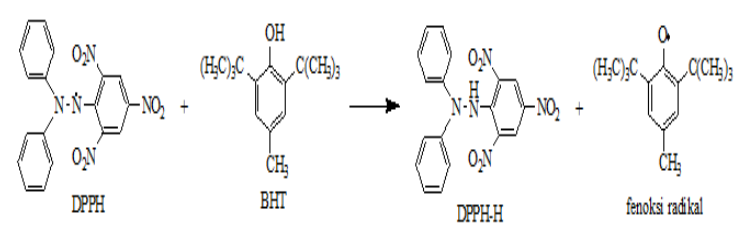

Figure 3 Reaction between BHT and DPPH
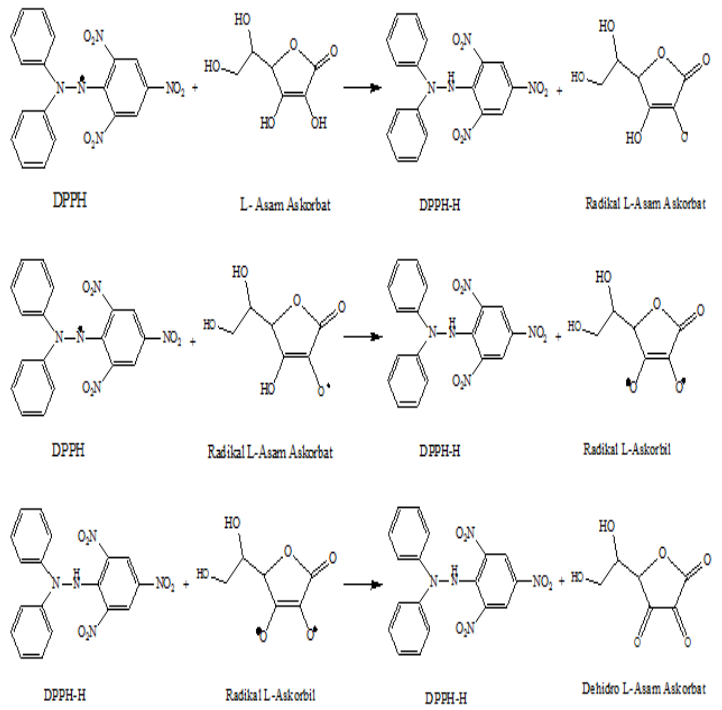

Figure 4 Reaction between Asc and DPPH

\section{Phytochemical Screening}

Phytochemical screening is a method to undestand plant base on the compound and a first information to determine secondary metabolite and bioactivity of plant (Teyler, 1988). The screening was applied to terpenoid, flavonoid, saponin, tannin and alkaloid. The screening tests showed in Table 4.

Table 4 The screening result of secondary metabolite of BCE

\begin{tabular}{|c|c|}
\hline Compound & Result \\
\hline Terpenoid & - \\
\hline Flavonoid & + \\
\hline Saponin & - \\
\hline Tannin & + \\
\hline Alkaloid, including: & \\
- Mayer Reagent & - \\
- Dragendorff & ++ \\
- Reagent & ++ \\
\hline
\end{tabular}

\section{CONCLUSION}

- The antioxidant activity of ethanol extract of black cumin was $22.483 \%$ and $\mathrm{IC}_{50} 2743.59$.

- Phytochemical screening showed presence of flavonoid, tannin and alkaloid. 


\section{REFERENCES}

Best, B. 2006. General Antioxidant Actions.www.benbest.com/nutrceut/ Antioxidant.html. Accessed on March 14 ${ }^{\text {th }}, 2009$.

Brand-Williams, W. 1995. Use of Free Radical Method to Evaluate Antioxidant Activity. Lebensmettel, Wissenschaft and Technologie.

Favier, A.E. 1982. Biological Indicators of Oxidative Stress in Humans. Trace Elements and Free Radicals in Oxidative Disease. Champaign Illiois.

Hanani, E., Abdul, M. danRyany, S. 2005. Identifikasi Senyawa Antioksidan dalam spons Callyspongia sp Dari Kepulauan Seribu. Majalah Ilmu Kefarmasian, Vol. II (3): 127-133. ISSN: 1693-9883.

Hendrik. 2009. Habbatus Sauda'. Tibbun Nabawiy Untuk Mencegah dan Mengobati Berbagai Penyakit. Solo: Pustaka Iltizam.

Kunchandy, E. dan Rao, M.N.A. 1990. Oxygen Radical Scavenging Activity of Curcumin. International Journal. Pharm., Vol. 58: 237-240.
Molyneux, P. 2003. The Use of The Stable Free Radical Diphenylpicryhydrazyl (DPPH). For Estimating Antioxidant Activity. Songklanakarin, J.Sci. Technol. 26 (2): 211-219.

Mun'im, A., Negishi, O. Dan Ozawa, T. 2003. Antioxidative Compounds From Crotalaria sessiliflora, Biosci. Biotechnol. Biochem, Vol. 67 (2); 410-414.

Prakash, A. Rieglhof, F., dan Miller E. 2001. Medallion Laboratories: Analytical Progress. Antioxidant Activity.www.terranostrachocholate .com /file/Comparative_and_General _Antioxidant_information. Accessed on March $14^{\text {th }}, 2009$.

Rohman, A., Sugeng, R. dan Diah, U. 2005.Antioxidant Activities, Total Phenolic and Falvonoid Contents of Ethyl Acetate Extrct of Mengkudu (Morindacitrifolia, L.)Fruit and Its Fractions. Fakultas Farmasi. Universitas Gadjah Mada. Yogyakarta. 